地すべり 第27巻 第 4 号

Journal of Japan Landslide Society 27-1 (1990)

\title{
有限要素法による地すべりの安欵解析と対策工の設計
}

\section{Slope Stability Analysis and Prevention Work Planning by FEM}

\author{
藤 田壽 雄* \\ Hisao Fujita
}

\begin{abstract}
The limit equilibrium method has been used for the stability calculation of landslide submerged by reservoir water. However, it is difficult to evaluate the relationship between sliding distance and porewater pressure. The slope stability calculatioh by F.E. M. combined with joint element is studied to clarify the strain and stress condition along the slip surface, and also to analize the stress of steel pile and anchor works constructed in landslide area. In this paper, the claculation procedure by F. E.M. is discussed.
\end{abstract}

キーワード : 有限要素法, 水没斜面, 浸透流, 杭工, アンカーエ

\section{1. まえがき}

ダム貯水による水没斜面での地すべり発生について湛 水位の変動状況及び地すべり発生時の標高から地すべり 発生タイプを分類すると,

(1) 初期湛水時に発生する地すべり

（2）湛水位が比較的一定な状況下で発生する地すべり

（3）湛水位の急速低下時に発生する地すべり に大別できる(1),2)、3)

したがって, 水没地すべり斜面の安定度評価に执いて は, 土塊の強度低下以外, 斜面内の地下水位変動による 精度の高い間隙水圧の評価が必要となる。これら目的に 従い, 水没地すべり斜面について有限要素法による飽和 ・不飽和浸透流解析和よび対策工を勘案した斜面安定解 析を実施したので報告する。

\section{2. 水没地すべり斜面の間隙水圧推定}

有限要素法による飽和・不飽和浸透流解析法が Neu$m a n^{4)}$ によって提案され, 従来の飽和浸透流解析でみ られた自由水面の接点を各時間ごとに移動させる必要が なくなり，計算スキームが簡単化されるとともに複雑な モデルでも解析が可能となり, 後述する対策工を含めた 斜面安定解析のための有限要素網と容易に連結出来るこ ととなった。

\section{1 飽和・不飽和浸透流解析の支配方程式}

飽和・不飽和状態の土中を運動する地下水に対する連 続式は次式で与えられる

$$
-\operatorname{div} \rho v=-\nabla \cdot \rho v=\frac{\partial}{\partial t}(\rho \theta)
$$

ただし, $\rho$ : 水の密度, $v:$ 水の流速, $\theta:$ 体積含水率

* 砂防・地すべり技術センター
上式に土中の水の運動を規定する運動方程式として透 水係数が体積含水率の関数とした上で, 輸送現象の場合 と同様な考え方より導かれた Darcy・Buckingham の方 程式

$$
v=-k(\theta) \cdot \nabla h
$$

ただし, $k:$ 透水係数, $h:$ 全水頭

を代入し, 全水頭を圧力水頭と位置水頭で表現し，水の 密度が空間, 時間に対して不変であり, 体積含水率と圧 力水頭の 2 変数を持つ偏微分方程式を 1 つの変数を基準 にした方程式に変換し, 重み付き残差法により整理を行 う最終的に次式が求められる。

$$
\begin{gathered}
A_{n m} \psi_{m}+F_{n m} \frac{\partial \psi_{n}}{\partial t}=Q_{n}-B_{n}-D_{n} \\
A_{n m}=\sum_{e=1}^{n} k_{i j} k_{e} \int_{v} N_{e} \frac{\partial N_{n}}{\partial x} \frac{\partial N_{m}}{\partial x} d v \\
\quad+\sum_{e=1}^{n} k_{i j} k_{e} \int_{v} N_{e} \frac{\partial N_{n}}{\partial z} \frac{\partial N_{m}}{\partial z} d v \\
F_{n m}=\sum_{e=1}^{n} \int_{v}\left(C_{e} N_{e} N_{n}+\alpha S_{s} N_{n}\right) d v \\
Q_{n}=\sum_{e=1}^{n} \int_{n} N_{n} \cdot q d s \\
B_{n}=\sum_{e=1}^{n} k_{i j} k_{e} \int v N_{e} \frac{\partial N_{n}}{\partial x} d v \\
D_{n}=\sum_{e=1}^{n} S_{q} N_{n} d v
\end{gathered}
$$

ただし， $N$ : 形状関数, $\phi$ : 圧力水頭, $S_{s}$ : 比貯留係数, $q$ : 要素境界部での流出入量, $S_{q}$ : 領域内の流出入量

\section{2 事例解析}

解析に使用した地すべり地は，高知県大渡ダム貯水池 周辺に位置する森山, 戸崎地区である。解析計算は貯水 
位.上昇と下降期の存在する試験湛水の実施された昭和 60 年10月22日より昭和61年 7 月 9 日に至る期間である。

森山地区に打いては，比較的良く地下水位の観測がな されているB，Cの 2 測線について浸透流解析を奏施し た。三角形要素分割は後述の斜面安定解析の際に必要な すべり面での間隙水低分布特性を正確に把挃するためす ベり面の形状を配虑した。

計算結果は，眝水位㤎動に伴なって境界条件が変化寸 る非定常解析であるので貯水位の变動速度が急变する時 期で出力することとし，その時期に扣ける地下水位顴測 結果と対比することとした。

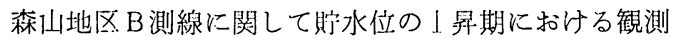
值と計算結果を四-1に示す。当図によれば，標高 155.5 $\mathrm{m}, 188.5 \mathrm{~m}$ で地下水位観測值と計算値間には落干の柏 違が見られる。これは現地地すべり地における地下水位 観測手法がボーリング孔内の水位をフロートによって自

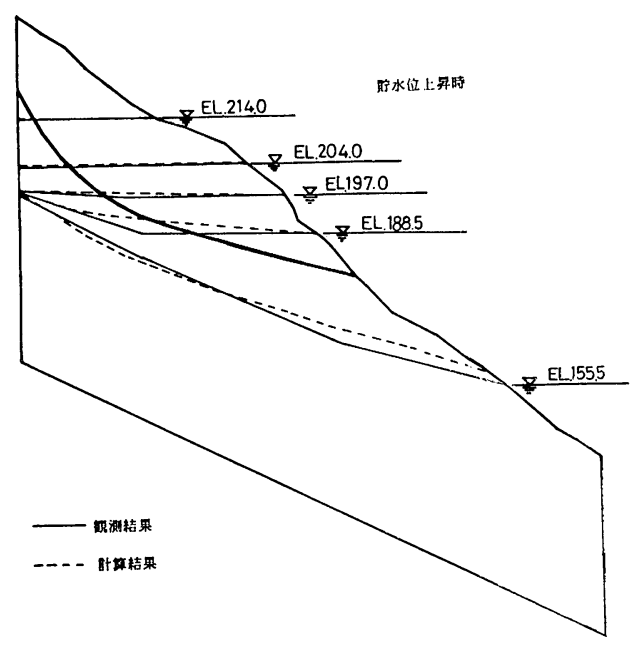

图-1 森山地区（B断面）観測值と計算值比較

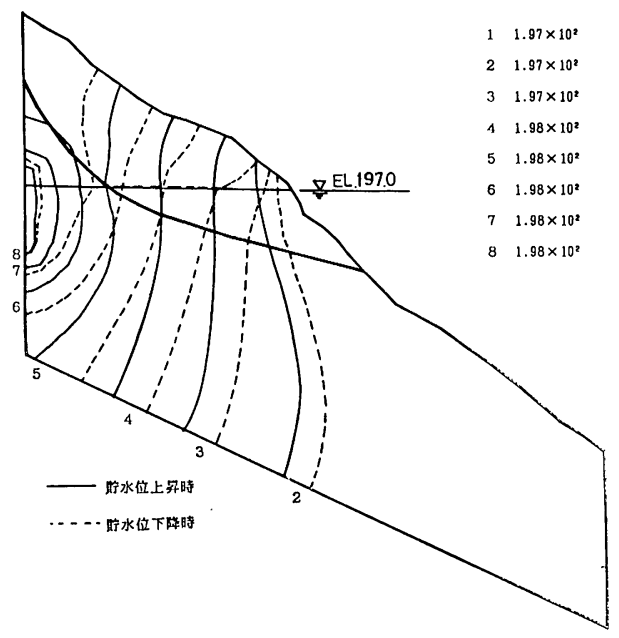

图-2 森山地区（B断面）全水頭分布図
記記録するといらものであるため，観測值に誤差を含ん でいることが最大の原因であると思われる。図-2には， 森山地区B断面に打ける詝水位の上昇, 下降時に打ける 同一财水位標高に拈ける全水頭分布図を示した。䝪水位 上罪と下降時の地すべり地内地下水位標高は同じであっ ても，すべり面に作用する全水頭分布值は相沿している。 従来の水没地すべり斜面の安定解析比いてては水位標高 より間隙水王を推定していたため同じ地下水位の場合同 じ間隙水王値を与えることとなっていたが，今间実施し た解析の結果から判断すると従来の可法では贴水位上帠，

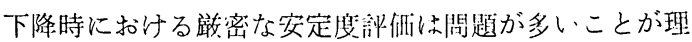
解される。

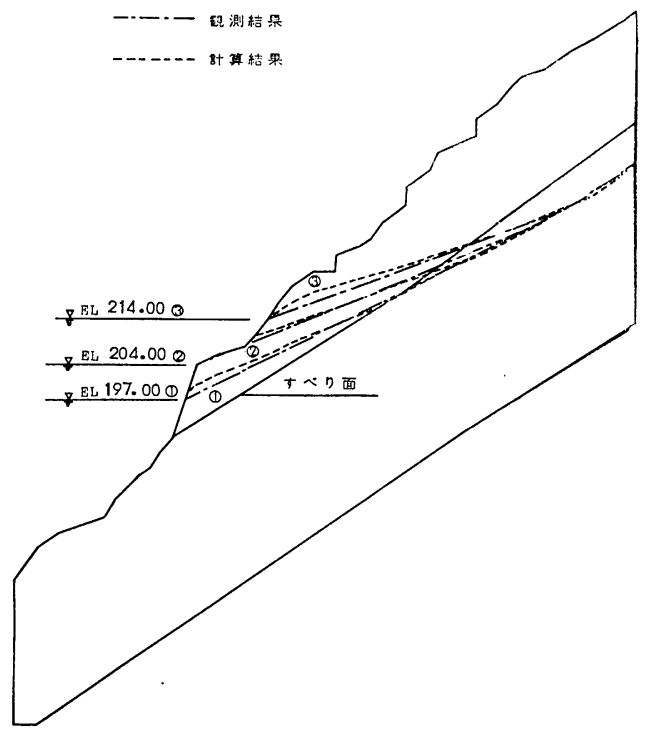

図-3 戸崎地区観测值と計算値の比較

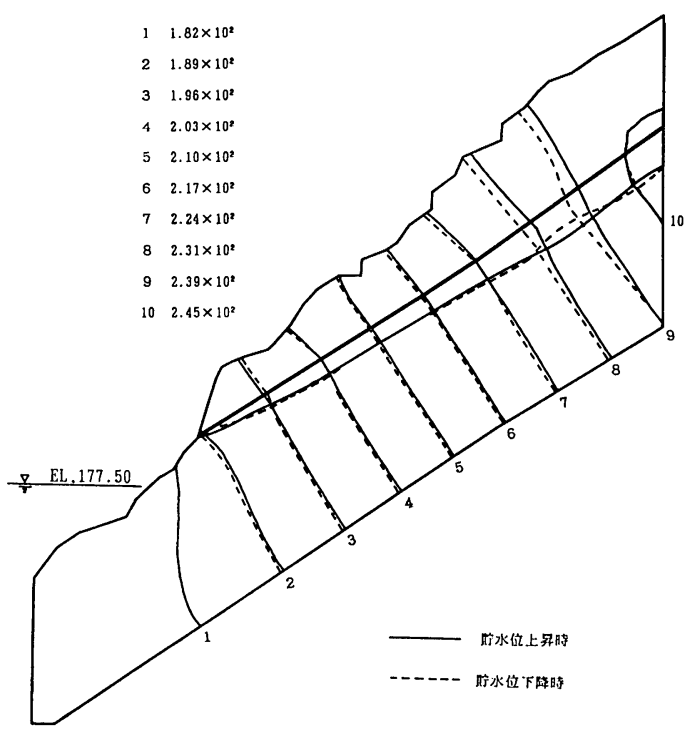

図-4 户崎地区全水頭分布図 
戸崎地区は昭和57年度に実施された試験湛水期間中に 地すべりが発生した箇所である。罒-3に観测值と計算值 の比較結果を示す。図-4に森山地区を同様に同じ貯水位 標高に拈ける低下，上昇時の全水頭分布を示す。解析結 果によれば森山地区と相違して貯水位上异時と低下時の 全水頭分布に相違は認められない。これは当地区が森山 地区と相違して比較的急傾斜面であるため残留間隙水圧 の残余が少ない理由による。このように残留間隙水王の 分布は斜面の形状及び，これを構成する土塊の透水係数 等の影響を受ける。

\section{3. 対策工を勘案した斜面安定解析}

最近になって, 応力法 (有限要素法) ${ }^{13)}$,14) による解 析が，材料の非均質性执よび力学的特性の非線形性，さ らには不連続性及び複雑な境界条件等容易に解析に取り 入れることが可能なため盛んに地盤工学の分野で活用さ れている。これら有限要素法による斜面安定解析は, 地 すべり土塊の応力と歪の関係を用い，すべり面での安全 率の一意性を求めないため, 前述の地すべり頭部, 末端 部スライスでの安全率の相違を比較検討することが可能 である。しかしながら，地すべり斜面の安定性について 有限要素法を用いて 論じた 報告は非常に少ない(15),16)。 地すべり斜面の安定性問題において有限要素法が適用さ れなかった理由としては, 各地盤材料の力学モデルへ導 入される材質定数の不確定さ, すべり面粘土の土質力学 的特性を反映したモデルの有限要素法での確立が困難で あったことに起因していると思われる。

一方，地すべり対策工としての抑止工を考えると，抑 止工の概念からして地すべり土塊の変形あるいは滑動力 に応じてこれら対策工はその抑止力を発揮する。したが って, 本来ならば杭工の設計は地すべり土塊の許容変形 量を設定後, 杭工の剛性等を決定すべきであると考えて いるが，従来の極限平衡法による斜面安定解析式には歪 の概念が導入されていないこと，および企を基にした杭 工の設計の解析が非常な困難を伴うことから簡便的な手 法が用いられて来た。特殊要素を勘案した有限要素法17) を利用すると直接応力〜亚関係を用いるのでこれら問題 点は合理的に処理可能となる。

\section{1 地すべり斜面の有限要素法のためのモデル化}

地すべり斜面の安定解析に拈いては，斜面に潜在また は明瞭に存在するすバり面特性を有限要素解析モデルに 組み込む必要がある。土質構造物や岩盤構造物の安定性 の検討の際に用いられている不連続面としては18)

(1) 構造物と地面との接触面や岩盤内の断層やジョイ ントなどのよらにあらかじめ系全体に拈ける不連続面 (弱面, すべり面, はく離面等) が明らかである場合

(2) 応力あるいは歪の状態に応じて発生する局所的な 破壊面やさらにはそれから進展する遂次破壊面のように,
あらかじめ不連続面の位置や方向が明確にできない場合 に区分することができる。

不連続面を表現する要素としては，これまでに Goodman 型19) と Zienkiewicz 型20)が提案されている。前者 は不連続の厚さが零のジョイント要素を考光, その相対 するジョイント方向での変位と平均的な力の関係を用い, 単位長さ当りのジョイントに対する垂直方向剛性と接線 方向剛性がジョイントの力学的特性を表すとしている。

一般に，現実の地すべり斜面でのすべり面は，スリッ ケンサイドと呼称される薄層として観察されることが多 い21)。ある場合にはすべり面上部に擋乱された粘土層が 見られることもあるが，すべり層は移動土塊層に比較し て非常に薄い場合が多い。これら現地観察結果から判断 すると残留強度特性に焦点をあてた, 要素の厚さを考え ないGoodman 型のジョイントが当面の目的に適うと考 えられる。

有限要素法による斜面安定解析法は Zienkiewicz ${ }^{22)}$ に よって詳しく述べられているが，すべり面の力学的特性 をジョイント要素で表わし, Goodman によって与えら れた変形モードを導入すればジョイント要素の応力と歪 は次式で表わされる剛性特性で与えられる。

$$
\left\{\begin{array}{c}
\Delta \sigma_{s} \\
\Delta \sigma_{n} \\
M_{0}
\end{array}\right\}=\left|\begin{array}{ccc}
k_{s} & 0 & 0 \\
0 & k_{n} & 0 \\
0 & 0 & l 3 k_{n} / 4
\end{array}\right|\left\{\begin{array}{c}
U_{0} \\
V_{0} \\
\omega
\end{array}\right\}
$$

たたし， $\sigma_{s}$ : 水平応力, $\sigma_{n}$ : 垂直応力, $M_{0}$ : モーメン

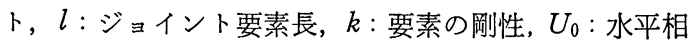
対変位, $V_{0}$ : 垂直相対変位, $\omega$ : 回転量

よって，ジョイント要素の節点変位とそれに対応する外 力増分の関係は次式で与えられる。

$$
\{\Delta F\}_{s . n}=[k]_{s . n}\{U\}_{0}
$$

アンカー工の特性としてはアンカー工の軸力のみ評価す るため棒要素を適用する。棒要素の剛性マトリックス表 示式を求めると次式が得られる。

$$
\{P\}=\frac{E A}{L}\left|\begin{array}{rr}
1 & -1 \\
-1 & 1
\end{array}\right|\left\{\begin{array}{l}
\delta_{1} \\
\delta_{2}
\end{array}\right\}=[k]
$$

ただし, $P$ : 外力, $E$ : 弾性係数, $L$ : 要素長, $\delta:$ 丕量 杭の特性としては, せん断力, 曲げ応力が作用するの で本解析では梁要素でモデル化すると次式が得られる。

$$
\begin{aligned}
& \left\{\begin{array}{l}
P_{1 x} \\
P_{2 y} \\
M_{1} \\
P_{2 x} \\
P_{2 y} \\
M_{2}
\end{array}\right\}=\left[\begin{array}{ccc}
E A / L & 0 & 0 \\
0 & 12 E I / L^{3} & 6 E I / L^{2} \\
0 & 6 E I / L^{2} & 4 E I / L^{2} \\
-E A / L & 0 & 0 \\
0 & -12 E I / L^{3} & -6 E I / L^{2} \\
0 & 6 E I / L^{2} & 2 E I / L^{2}
\end{array}\right.
\end{aligned}
$$

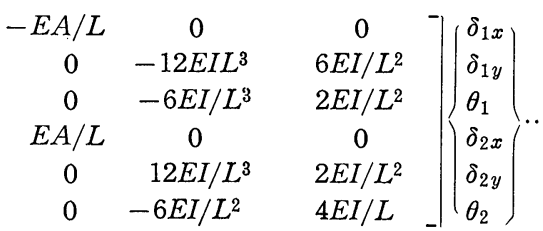


ただし， $\theta$ : たわみ你， $X$ : 要絷断面䅪，その他の記 号は棒要素と同じである。

したがって，本解析では(4)，(5)，(6)式の基本剛性方程: 式を整理後離散化し，杭工あるいはアンカー工施工位置 相当の有限要素節点に重社合わせ荷重增分法によりこれ ら剛性マトリックスを解くことにすれば，杭工扣よびア ンカー工等の抑止工を葚案した地すべり斜面の安定度評 洒が実施出来ることとなる。

\section{2 杭工 およびアンカーエを勘案した斜面安定解 析例}

本解析手法に颃いては地すべり土塊及び地山を弾性力 学モデルで，地すべり面を弾塑性型の特性を有するジョ イント要素で表わし，抑止工としての抑止杭を曲げ渢性 と軸力剛性が考虑可能な梁要素で, アンカー工は軸剛性 のみ考虑可能な棒要素でモデル化する。ジョイントの剛 性は表一1に示す值を用いた。すなわち，ピーク強度に達 するまではセン断剖性はG 1 で，ピーク強度以外の剛性 はG 2 で，それ以降は残留強度で与えられる。また，す ベり面のセン断強度はクーロンの破㙲基蕉を適用する。 以上の概念を基に，有限要索法による解析モデルの条件 を次のように設定した。

(a) 単位体積重证は，大渡ダム森山地すべり地区の抑 此工設計の際に用いられた極限平衡解析に使用された值， $1.8 \mathrm{t} / \mathrm{m}^{3}$ とする。

(b) 地すべり土塊及び地山の弾性係数及びポフソン比 は，森山地区士質調査報告害:23) より，弾性係数值につい て移秘㬝で 3, $200 \mathrm{tf} / \mathrm{m}^{2}$, 不動層では $4,700 \mathrm{tf} / \mathrm{m}^{2}$ とした。

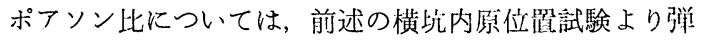
性係数算出に用いられている0.25を採用した。

(C)すべり面の粘着力，内部㯲擦角は，森山B測線上 り採取されたすべり面土塊強庤より, 粘着力 $3.0 \mathrm{tf} / \mathrm{m}^{2}$, 内部摩擦角 $22^{\circ} 08^{\prime}$ と設定した。尹崎地すべり地区では土 質試験絬果がないので森山地すべり地区土塊より類推し て, 粘着力 3. $0 \mathrm{t} f / \mathrm{m}^{2}$, 内部摩擦佮 $34^{\circ} 01^{\prime}$ と設定した。

(d) すべり面のセン断剛性係数, 垂直剛性係数は, 前 述の森山地すべり地区で央施された $\mathrm{T}$ 一 2 横坑内の原位 踾セン断試験結果の応力 変位曲線図上り求め, 引張側 の垂直剛性係数は压縮倒の $1 / 10$ とした。

(c) 杭工の条件は, 杭種 : 鋼管付フレキシブル鉄筋コ ンクリート杭, 杭径: $\phi 406.4 \mathrm{~mm}$, 杭間隔: $1.2 \mathrm{~m}$, 配 列：千鳥配列，杭長：21.0mである。一方，アンカー工 は, 鋼線：PC 鋼線 7 本より $12.7 \mathrm{~mm} 12$ 本, 施工間隔:

表-1 すべり面の物性值

\begin{tabular}{|c|c|c|c|c|c|}
\hline 训 锞 & $\mathrm{G}_{1}\left(\mathrm{~kg} / / \mathrm{cal}^{3}\right)$ & $1 \mathrm{k},(\mathrm{kg} / \mathrm{cm})$ & $\mathrm{K}_{2}\left(\mathrm{kgf} / \mathrm{cul}^{3}\right)$ & $c\left(t t / \mathrm{m}^{2}\right)$ & $\phi\left(c^{\circ}\right)$ \\
\hline F汻地区 & 8. 0 & 4.0 & 40.0 & 3. 0 & 34.1 \\
\hline 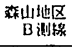 & 8. 0 & 4. 0 & 40.0 & 3. 0 & 22. 14 \\
\hline 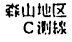 & 8. 0 & 4. 0 & 40.0 & 3. 0 & 14 \\
\hline
\end{tabular}

横断方向 $4.0 \mathrm{~m}$ ，維断方向 $4.0 \mathrm{~m}, 10$ 段，断面積：11.845 $\mathrm{cm}^{2}$, 初期緊張力： $60 \mathrm{t} / 1$ 本である。解析に当たっては, アンカー段数を10段汇設定すると解析領域の規模から判 断して要素数が增加するので 5 段ピッチの計算を実施し た。なお，本解析では，B測線に执いてアンカー工と杭 工の抑止効果の比較検討を行らため仮想抑止杭を設定し, その応力解析も実施することとした。その仮想杭の設計 条件は次のよら設定する。すなわち，フンカー工の設 計を基本として，必要抑止力：306.66 t （アンカー抑止 力と同じ), 恨入れ長: $11.2 \mathrm{~m}$ (全長の $1 / 3$ ), 杭全長 : $34.0 \mathrm{~m}$, 杭径：杭径については曲げモーメントより検討 し，杭径 508.0mm が得られた。

解析の対像とした 3 測線（戸崎地区，森山 B , C 測線） の各計算結果は玟-2の計算結果一筧婊に示す。以下に今 回実施した各測線の解析結果について詳述する。

\section{1） 戸崎地区}

当地区は抑止工なしで聍水位が低水位（標高 $188.5 \mathrm{~m}$ ) の場合と，低水位から高水位（標高204.0m）に上昇さ せた場合の辣算のみ実施した。すなわち，当地区は試験 湛水位時の標高 $204 \mathrm{~m}$ の貯水位で地すべりが発生したた めである。

解析ケースは表-2の1，2 ケースで解析結果として初 期応力時のすべり面の応力状態及び安全率分布を図-5に 示ず。れによるとすべり面の頭部より下流域の $1 / 4$ の䇛囲をで安全率は 1.00 となる。すなわち塑性状態を示 して橴，すべり面土塊強度が残留強度へ低下している。 この時のすべり面全領域のセン断力とセン断抵抗力の比, いわゆる極限平衡法でいうすべり面安全率は Fs=1.130

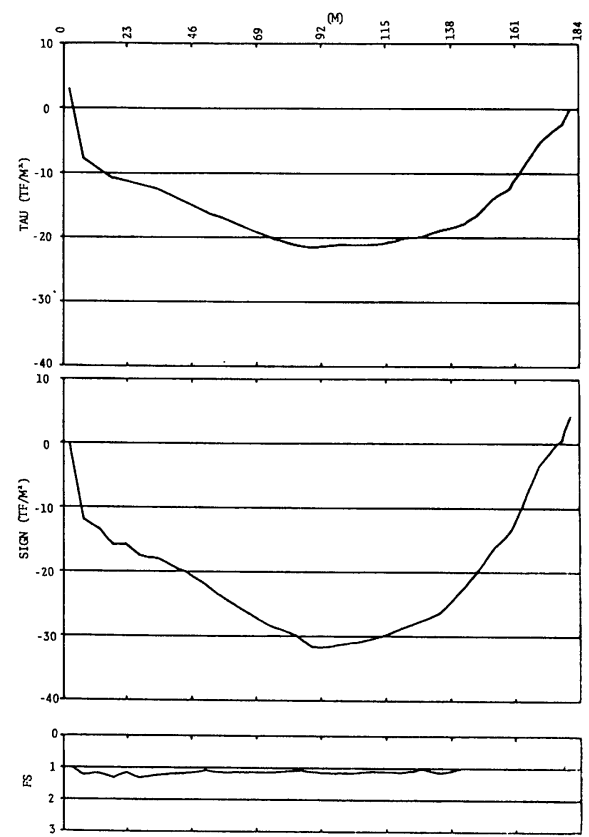

图-5 すべり面の応力状態（初期応力ー戸崎测線） 
表-2 計算結果一覧表

\begin{tabular}{|c|c|c|c|c|c|c|c|c|c|c|c|c|c|c|c|}
\hline \multirow{2}{*}{ 训绿名 } & \multirow{2}{*}{ it } & \multirow{2}{*}{ 抑止工 } & \multirow{2}{*}{$\begin{array}{c}\text { (1)水位 } \\
(\mathrm{m})\end{array}$} & \multirow{2}{*}{ 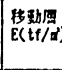 } & \multicolumn{2}{|c|}{ 抵纷打 $(t)$} & \multicolumn{2}{|c|}{ 经到力 } & \multicolumn{2}{|c|}{ 安 全 事 } & \multicolumn{3}{|c|}{ 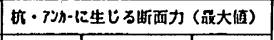 } & \multirow{2}{*}{$\begin{array}{l}\text { 份の安全安 } \\
\text { ( 世ん断) }\end{array}$} & \multirow{2}{*}{$\begin{array}{l}\text { アンカーの } \\
\text { 全 串 }\end{array}$} \\
\hline & & & & & ナベり方向 & 水平方向 & 绩り方向 & 水平方向 & ナベり方向 & 水平方向 & 䖵力 $(t)$ & 世人断力( $t)$ & $\mid t-x j k(t m)$ & & \\
\hline \multirow[t]{2}{*}{ F峈比区 } & 抽朋度力 & & - & 3200 & 3114.0 & 2449.0 & 2755.0 & 2150.0 & 1. 130 & 1.139 & & & & & \\
\hline & $\frac{1}{2}$ & & $\begin{array}{l}188.5 \\
204.0\end{array}$ & 3200 & $\begin{array}{l}3104.0 \\
2872.0\end{array}$ & $\begin{array}{l}2437.0 \\
2241.0\end{array}$ & $\begin{array}{l}2756.0 \\
2682.0\end{array}$ & $\begin{array}{l}2151.0 \\
2088.0\end{array}$ & $\begin{array}{l}1.126 \\
1.071\end{array}$ & $\begin{array}{l}1.133 \\
1.073\end{array}$ & & & & & \\
\hline \multirow{2}{*}{ 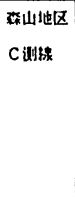 } & 劝明度力 & & - & 3200 & 1262.0 & 1040.0 & 1004.0 & 787.8 & 1.257 & 1.322 & & & & & \\
\hline & $\begin{array}{l}3 \\
4 \\
5 \\
6\end{array}$ & 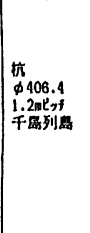 & $\begin{array}{l}177.5 \\
188.5 \\
214.0 \\
177.5\end{array}$ & & $\begin{array}{r}1016.0 \\
934.4 \\
690.1 \\
999.2\end{array}$ & $\begin{array}{c}805.2 \\
(811.88) \\
734.8 \\
(758.1) \\
561.8 \\
(588.9) \\
789.8 \\
(799.99) \\
\end{array}$ & \begin{tabular}{l|}
957.1 \\
878.8 \\
638.1 \\
945.6
\end{tabular} & \begin{tabular}{l|}
746.2 \\
679.2 \\
508.9 \\
736.4
\end{tabular} & $\begin{array}{l}1.062 \\
1.063 \\
1.082 \\
1.057\end{array}$ & $\begin{array}{l}1.079 \\
(1.088) \\
1.083 \\
(1.116) \\
1.104 \\
(1.153) \\
1.073 \\
(1.086)\end{array}$ & $\begin{array}{l}7.25 \\
27.0 \\
36.0 \\
11.28\end{array}$ & $\begin{array}{c}6.31 \\
21.2 \\
22.3 \\
9.48\end{array}$ & $\begin{array}{c}5.12 \\
18: 6 \\
21.2 \\
7.95\end{array}$ & $\begin{array}{l}52.81 \\
15.70 \\
14.95 \\
35.15\end{array}$ & \\
\hline \multirow{2}{*}{ 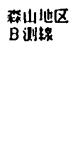 } & & & - & 3200 & 1171.0 & 971.6 & 081.9 & 790.4 & 1.191 & 1.229 & & & & & \\
\hline & $\begin{array}{l}7 \\
8\end{array}$ & 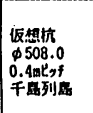 & $\begin{array}{l}188.5 \\
214.0\end{array}$ & 3200 & $\begin{array}{r}1107.0 \\
733.9\end{array}$ & $\begin{array}{r}907.9 \\
574.9 \\
(608.4)\end{array}$ & $\begin{array}{l}964.3 \\
738.1\end{array}$ & $\begin{array}{l}77.5 \\
578.3\end{array}$ & $\begin{array}{l}1.148 \\
0.994\end{array}$ & $\begin{array}{l}1.174 \\
0.994\end{array}$ & 25.0 & 24.6 & 47.4 & 52.68 & \\
\hline \multirow[t]{2}{*}{ 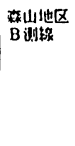 } & $\begin{array}{l}9 \\
10\end{array}$ & \multirow{2}{*}{ 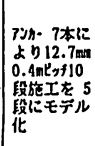 } & $\begin{array}{l}188.5 \\
214.0\end{array}$ & 3200 . & $\begin{array}{r}1155.0 \\
766.6\end{array}$ & $\begin{array}{c}951.3 \\
(1081.2) \\
614.1 \\
(747.1)\end{array}$ & $\begin{array}{l}874.1 \\
756.7\end{array}$ & $\begin{array}{l}691.5 \\
594.2\end{array}$ & $\begin{array}{l}1.521 \\
1.026\end{array}$ & $\begin{array}{c}1.376 \\
(1.564) \\
1.033 \\
(1.257)\end{array}$ & $\begin{array}{l}150.0 \\
153.52\end{array}$ & & & & $\begin{array}{l}2.243 \\
2.171\end{array}$ \\
\hline & & & & & & & & & & & & & & & \\
\hline
\end{tabular}

の值が得られる。

次に貯水位を標高188.5mから204.0 $\mathrm{m}$ に上杽させた場合の变位図を図-6に 示すが，地盤変位はすべり末端部付近 が大きい。この時のすべり面の応力状 態は図-7に示すと拉り，セン断応力が 滅少している。このためすべり末端よ り上部にわたって $1 / 4$ の領域が塑性状 態となり，その部分のすべり面での安 全率は 1.0 の值となっている。当戸崎 地区の試験湛水時の地すべり状沿は, 貯水位標高が $204 \mathrm{~m}$ に達した時地す心゙ り末端部のすべりが発生し，その後上 部が引きつうられるよらにして背後斜面 に大規模な地すべりが発生した。地す ベり末端部の地すべりによってその背 後の地すべりが移動する解析を実施す

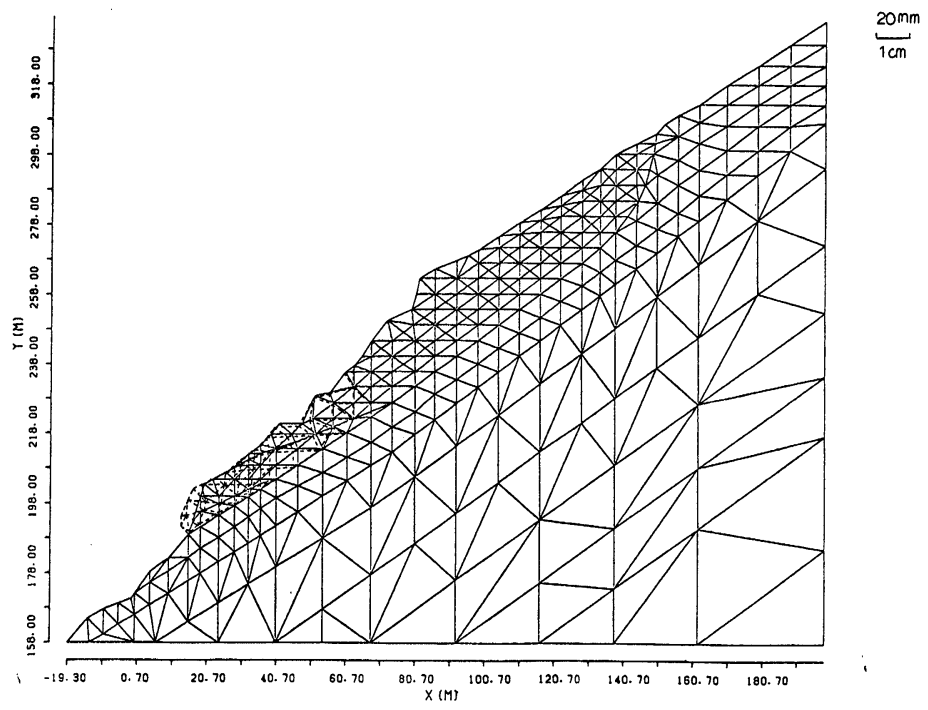
るには, その部分に引張応力特性が勘案可能なジョイン ト要素を導入しなければならない。今回はこの特性を導 入せず連続体として取り扱ったため，この背後斜面のす ベり面の安全率が 1.0 になるよらな計算結果は得られな かったが, 少なくとも今回得られた解析結果は, これら 戸崎地区の地すべり実態を説明し得るものと考える。

2）森山地区 $C$ 測線

本測線の 抑止工は 鋼管杭である。貯水位条件は標高 $177.5 \mathrm{~m}, 188.5 \mathrm{~m}$ と最高水位 $214 \mathrm{~m}$ 及び最高水位から標

図-6 地盤変位図 (CASE 2)

高 $177.5 \mathrm{~m}$ に低下させた場合の 4 ケース（3，4，5， 6 ケース) である。

この条件では，初期応力時にはすべり面中央部から頭 部域にかけて局所安全率は 1.0 となり, 塑性状態を示す。 この場合のすべり面安全率は 1.257 である。貯水位を標 高 $177.5 \mathrm{~m}$ まで上昇させると間隙水圧の増大によって塑 性領域が広がり,すべり面安全率は 1.062 となり, 初期 応力時より約 0.2 の安全率の低下が見られる。

さらに貯水位標高を $188.5 \mathrm{~m}$ まで上昇させると間隙水 


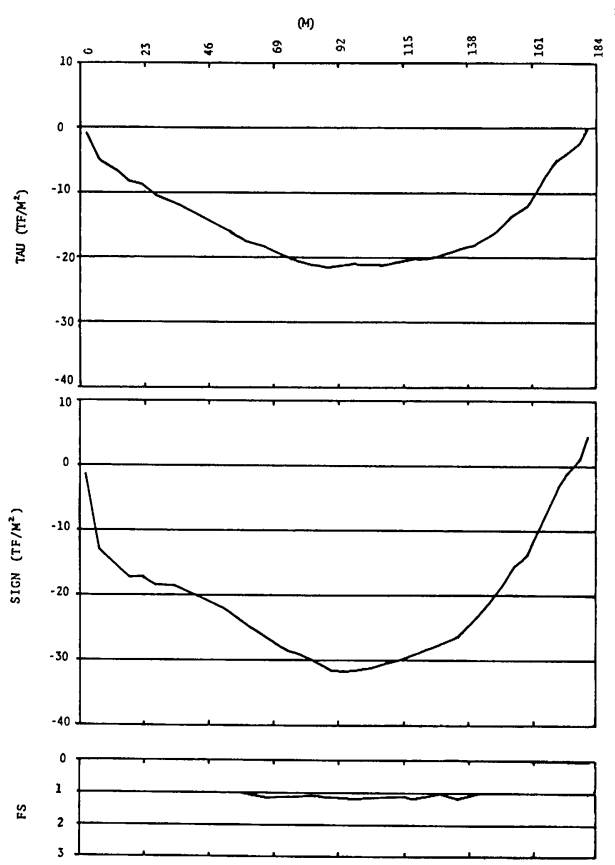

図-7 すべり面の応力状態（CASE 2)

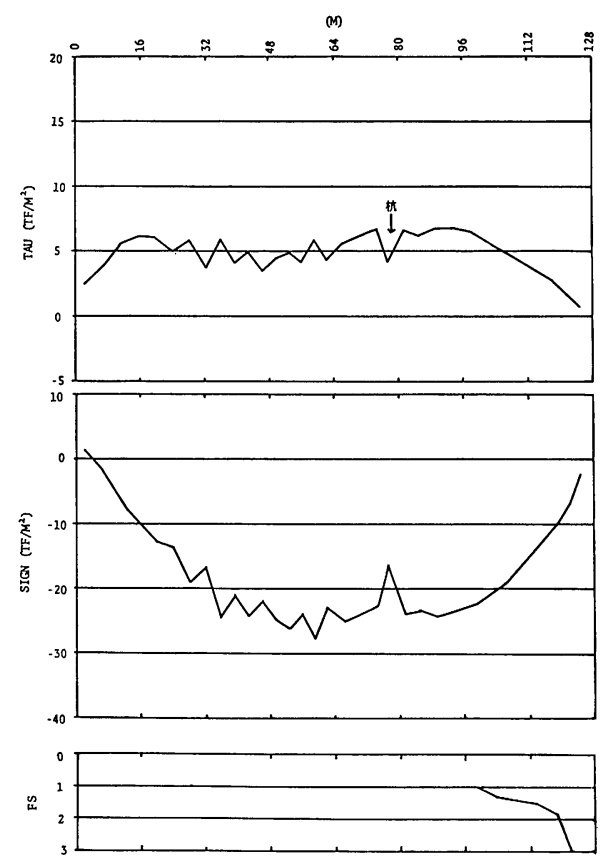

図-8 すべ面の応力状態（CASE 5)

压の増大によってすべり面の塑性領域 は貯水位標高 $177.5 \mathrm{~m}$ に比較してやや 昖大するが，すべり面の応力状態によ ればすべり面安全率は 1.063 となり相 違は見られない。しかしながら，杭に 作用する軸力は7. $25 \mathrm{t}$ から $27.0 \mathrm{t}$, 七 ン断力は6. $31 \mathrm{t}$ から $21.2 \mathrm{t}$, 曲げモー メントは $5.12 \mathrm{t} \cdot \mathrm{m}$ から $18.6 \mathrm{t} \cdot \mathrm{m}$ に增大 している。すなわち，抑止杭によって 抑止効果が発揮されていることが理解 される。この場合の抑止杭の変位量は すべり面位置で $0.6 \mathrm{~mm}$ から $2.0 \mathrm{~mm}$ と 增大している。

さらに貯水位標高を標高 $214 \mathrm{~m}$ まで 上昇させた場合すべり面の応力状態を 図-8，セン断力，モーメント分布を 図-9 10に示す。解析によると抑止杭

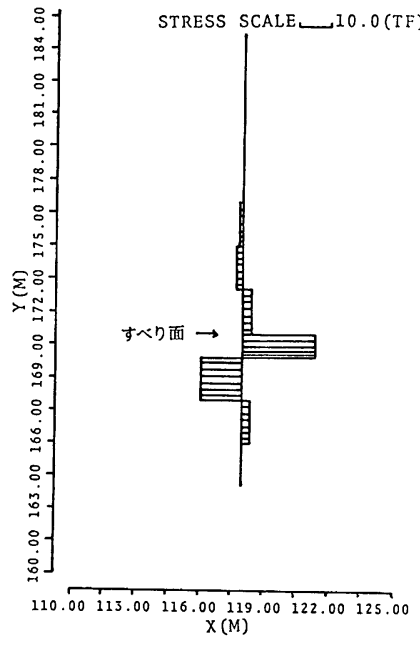

図-9 抑止杭のセン断応力分布 (CASE 5)

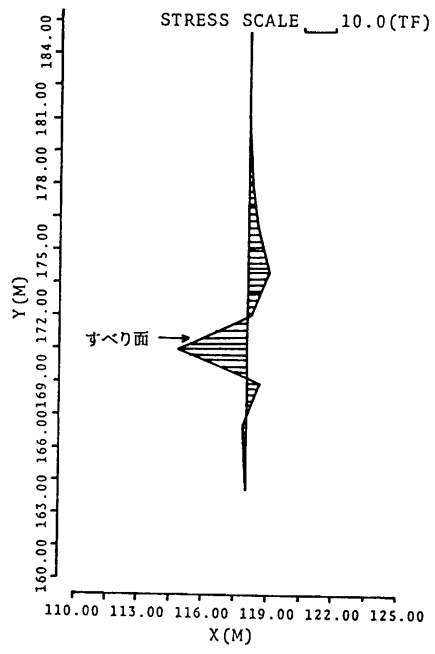

図-10 抑止杭のモーメント分布 (CASE 5)
の頭部変位量は $5.5 \mathrm{~mm}$ から $12.0 \mathrm{~mm}$ 一と増大する。抑止 杭は全体として変位量が大きくなるため軸力は $27.0 \mathrm{t}$ ら36.0 t へ, セン断力は21.2 $\mathrm{t}$ から $22.3 \mathrm{t}$ へ, 曲げモー メントは18.6t・mから $21.2 \mathrm{t} ・ \mathrm{~m}$ へと增加する。したがっ て，貯水位上舁によってすべり面強度は低下するが抑止 杭の抑止效果が発揮されるためすべり面安全率の極端な 低下は見られない。

さらに，貯水位が最高水位 $214 \mathrm{~m}$ より標高 $177.5 \mathrm{~m}$ 亿低 下した場合同じ貯水位標高でもすべり面汇作用する間䏚 水压が相違するためすべり面全領域の安全率は上昇時が
1.088であるが，下降時のそれは1.086となり，若干では あるが残留間隙水正の影響が見られる。

当地区では，抑止杭設置位置に抋いて孔内傾斜計によ る観測が実施されている。本解析期間に拈ける貯水位条 件と観測期間が一致する昭和 60 年 12 月 9 日の貯水位標高 $188.5 \mathrm{~m}$ (ケース 4) と括ける孔内傾斜計測定值と解析 結果を比較したのが図-11である。これによると，すべ り面付近の抑止杭の变位量は一致しているが，杭頭では 測定值が約 $2.1 \mathrm{~cm}$ であり, 解析結果は約 $0.6 \mathrm{~cm}$ と相違 がみられる。また，測定值では，すべり面から地表にか 
けて変位量が増加しているが, 解 析結果では深度 $8 \mathrm{~m}$ 付近より反対 に減少の傾向がみられ, 変形形態 は一致していない。この最大の理 由は,すべり面付近で実施された 横杭内原位置セン断試験結果を地 すべり土塊の土質特性として地す ベり地表部土塊特性にまで適用し たことによる。

3）森山地区B測線 $(7,8$, 9,10 ケース)

当地区に拁いては抑止工として アンカー工が実施されたが，前述 したよらにアンカーと杭工の抑止 効果比較を実施するため仮想杭の 設計を行い応力解析を実施した。 貯水位条件は，低水位（標高188.5 m）の場合と低水位から高水位 （標高 $214.0 \mathrm{~m}$ ）に上昇させた場 合について実施した。

(1) 杭工の場合 (7,8 ケース)

初期応力時には地すべり中央部から頭部域にかけて局 所安全率が 1.0 となり塑性状態を示している。この時の すべり面安全率は 1.192 の值が得られる。貯水位を標高 $188.5 \mathrm{~m}$ に上昇させた場合には地盤変位は生じないが, すべり面に作用する間隙水圧が増大するためすべり面安 全率が低下し，1.148の值が得られる。一方，仮想杭に は地盤変位が生じないため杭変位, セン断力, モーメン トの発生は見られない。さらに貯水位を標高 $214 \mathrm{~m}$ まで 上舁させるとすべり面全域が塑性状態を示し，すべり面 ジョイント部での局所安全率は 1.0 となるが, 地すべり 中央部に仮想杭が設置されているため仮想杭を加算した すべり面安全率は 1.052 となり，仮想杭によって0.06の 安全率が増加する。

（2）アンカー工設計の場合（9，10ケース）

解析の基本となる初期条件は仮想杭工と同じである。 貯水位標高を $188.5 \mathrm{~m}$ に上昇させた場合のアンカー工施 工により, 初期応力時の応力分布に比較してほぼすべり 面全域に括いて垂直応力が増加したセン断力が減少して いる。これはアンカー工の初期緊張力によるものである。 このためすべり面安全率は初期応力時に比較して増加し, 1. 321 の值が得られる。貯水位標高が $214.4 \mathrm{~m}$ に上昇する とすべり面の応力状態は末端を除いて塑性領域となり, すべり面安全率も 1.026 と低下する。

アンカー工の変位, 軸力分布, 定着部の軸及びセン断 応力分布を図-12〜13に示す。これによれば変位は斜面 上部のアンカー工の変位量が大きく, 下部に行くに従っ て小さくなる傾向がある。軸力は図に見られるように,
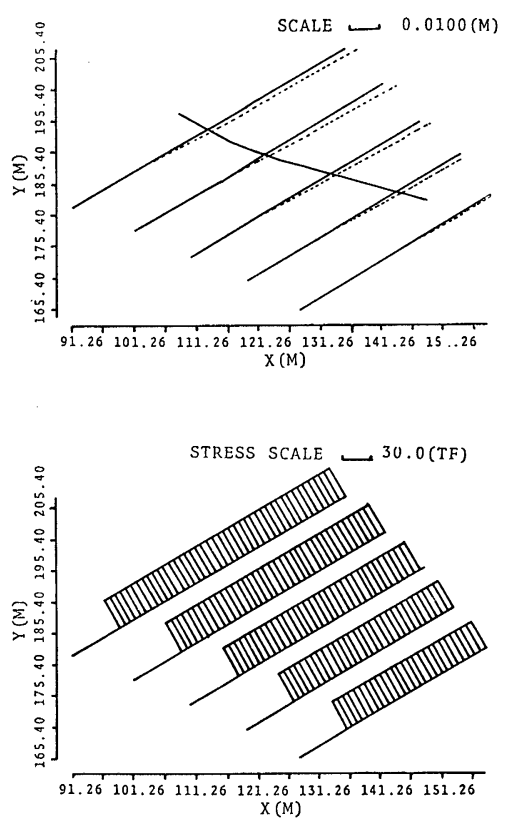

図-12 アンカーの変位及び軸力分布 (CASE 10)

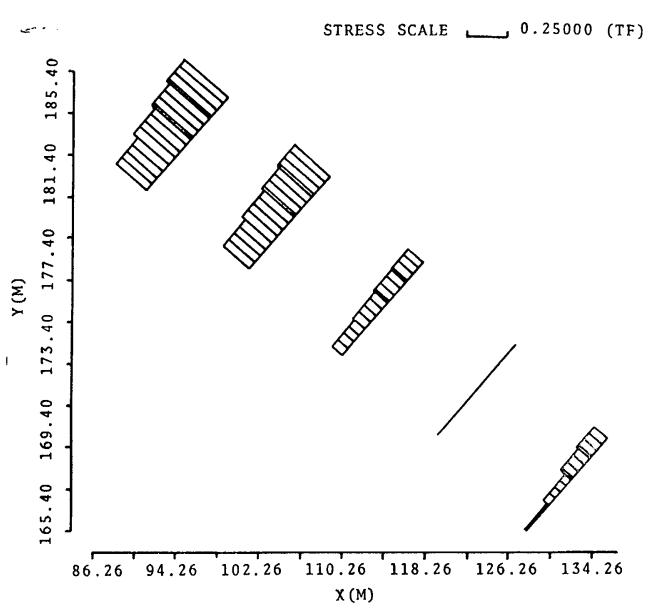

図-13 アンカー定着部の軸力分布（CASE 10）

自由長部の軸力の大きさは下方から二段目のアンカー工 の定着力部が最も小さい。こ沉はアンカー工群効果が発 揮されたためである。一般にアンカー工実施において初 期緊張力が大きいと定着部上部に応力が集中し, アンカ 一工定着部に扣いて順次深部に向かって鋼材と地山が剥 離すると言った進行性破壊現象が見られる。こう言った 定着部上部に応力が集中する現象は図-12にも見られる。 しかし，この現象は前にも述べたが群效果のちめ個々の アンカーエごとに相違がみられる。したがって, 多段施 エアンカー工の初期緊張力はすべてのアンカーエが均一 に地すべりに対して抑止效果を発揮するよらに計画され なければならない。アンカー工の軸力を加算したすべり 
面の安全率は貯水位 $188.5 \mathrm{~m}, 214.0 \mathrm{~m}$ のそれぞれで1.564, 1.257である。

当解析では，アンカー工と抑止杭との比較を笑施した が，设高水位でのすべり面安全率は前者が1.257 となり， 後者は 1.052 の值が得られる。この相造は抑止杭が完全 に地すべり土塊の変位に応じて抑止力が発揮されるのに 対してアンカーエはプレストレスを作用させる。このた め地すべり土塊の変位星が少なく,すべり面の塑性領域 も狭い。したがって，すべり面粘度の力学特性としてす ベり变位に忍じてピーク強度より残留強度へと低下寸る 性質を考虑すれば忼工に比較してアンカー工の方が有利 であると言える。

\section{4. 結 語}

地すべり斜面の安定解析は，一般に極限平衡法が用い られている。この手法によると地すべり移動量と間隙水 压の変動量について定量的評価は困難である。そこで地 下水位変動に伴うすべり面の忘力状態, 変位状態拉よび 抑止工模造物に生ずる応力特性を明らかにするため，有 限要素法による漫透流解析扣よび安定解析を实施し，現 実水没地すべり斜面と対比検討した。今回实施した解析 手法の特徴を要約すると以下の通りである。

1）水没地すべり斜面での残留間隙水王は，地下水標 高より推定するのではなく，有限要素等の解析によって すべり面の間隙水压を直接求めることが必要である。

2）有限要素法解析を夷施することによって，移動量 に応じたすべり面土塊のせん断抵抗力の評価, 特に残留 強㡲の特性を安定度評洒に反映出来る。

3）有限要素法解析を実施することによって地すべり 土塊の移動量に応じた抑止櫡造物の抑止力特性を検討す ることが出来る。

有限要素法解析で最も重要なことは, 解析に用いる材 料定数であり, 解析結果はこれら定数の信頼性に依存す る。したがって，有限要素法による非線形解析手法等の 解析技術の向上以上に材料定数把握のための調査手法の 確立が最も重要であると考えている。

な拉，事例解析を笑施するに当って利用した諸資料に 関しては，元四国地方建設局長中西秩氏の御好意を得た もので，誌上を借り厚く御礼申し上げます。

\section{参考文献}

1) Q.Zaruba and V.Mencl : Landslides and their Cont- rol, Elsevier Scientific Publishing Company, New York, pp.237 256, 1982

2) Hisao Fujita : Influence of Water Level Fluctuations in A Reservoir on Slope Stability, Bull. Int. Asso. Eng. Geolo. No.16, pp.170 173, 1977

3）藤田寿雄 : ダム聍水池周辺の地すべり機構と対策，ダム技 術, Vol.3, No.1, pp.12 26, 1985

4) S. P. Neuman : Saturated Unsaturated Seepuge by Finite Elements, Proc. ASCE. Vol.99, No.12, pp. 2233 2250, 1973

5）大西有三：浸透，士筫・基礎工学における有限要素法の適

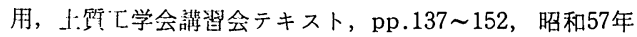

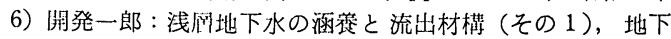
水と井戸とポンプ, 第 26 巻, 第11号, pp.9 17, 1984

7）藤田㚘雄・吉松弘行・坂元靖秀 : 水没斜面の安定解析手法 について, 土木研究所資料, 第 1909 学, p. 50 , 昭和 58 年

8) N. R. Morgenstern and V.E. Price: A Numerical Method for Solving the Equation of Slope Stability of General Slip Surfaces, The computer Journal, Vol.19, No.4, pp.388 393, 1967

9) A.W.Bishop: The Use of Pressure Coefficients in Practice, Geotechnique, Vol.4, No.4, pp.148 152, 1954

10) N.Janbu : Slope Stability Computaions, Embankment and Dam, Engineering, pp.47 86, 1973

11）中村浩之：地すべり斜面の安定計算式の検討，上木技術資 料, Vol.20, No.8, 1978

12）川本治：スライス間力を考虛した極限平衡法の検討と地 すべり斜面安定解析の適用, 農土試技報, C 22, pp.53〜 86, 1981

13）G．グーデフス著・川本朓万・桜井春輔・足立紀尚共㔚： 地船力学の有限琶装解析 1 , 森北出版, p. 324,1981

14）川本朓厅・林 正夫：地盤工学における有限要素解析, 土 岓力学と岩盤力学へのアプローチ, 培凡館, p.448, 昭和 56年

15）包人瀬地すべり調全報告䇆，上研凟料，1323号，昭和53年

16）島 通保：地すべり移秐機構の粘弾性的解橎について, 地 すべり, Vol.11, No.4, pp.1〜8, 1974

17）藤田替雄・吉松弘行・白石一夫：地すべり対策杭の挙動之 その解析, 地すべり, Vol.25, No.3, pp.15 22, 1988

19）土犋・基礎工学における有限要素法の適用, 讙㥜会テキス 卜, 土犋工学会, 昭和 57 年

20) R. E. Goodman, R. L. Taylor and T. L. Brekke : A Model for the Mechnics of Jointed Rock, Proc. A SCE, Vol.94, SM 3, pp.637 659, 1968

21) O.C.Zienkiewicz: Analysis of Nonlinear Problems in Rock Mechanics with Particular Reference to Jointed Rock System, Pros. 2nd, Congr. ISRM, Beoggrad, pp.8 14, 1970

22）玉田文吾：口之津地すべり 面形成過程について（I），地 すべり, Vol.7, No.4, pp.1〜8, 1971

23) O.C. Zienkiewicz：基礎工学におけるマトリックス有限 要素法, p.369, 培凡館

24）昭和 50 年大渡ダム地すべり調查報告茟, 四国地方建設局, 大渡ダム工事事務所, 昭和 51 年 2 月

（原稿受理日 平成元年10月30日） 